\title{
THE IMPACT OF THE RELIABILITY OF THE ACCOUNTING INFORMATION SYSTEM UPON THE BUSINESS PERFORMANCE VIA THE MEDIATING ROLE OF THE QUALITY OF FINANCIAL REPORTING
}

\author{
Ahmed Al-Dmour \\ Brunel University \\ United Kingdom
}

\begin{abstract}
This study aims to examine the relationships of the reliability of the Accounting Information System (AIS) based on the implementation of SysTrust's framework (principles and criteria) as an internal control method to the business performance and the mediating role of the quality of financial reporting in this relationship among Jordanian public listed companies. Based on the literature review and contingency theory; an integrated conceptual framework was developed to guide this study. The study's conceptual framework consists of three major constructs: the reliability of AIS was conceptualized and measured by the SysTrust's framework (principles and criteria) the business performance was measured by the financial and non-financial indicators and the quality of financial reporting was conceptualized and measured by the IASB's framework fundamental qualitative characteristics. A total of 239 responses were obtained through a self-administered questionnaire from PLCs in the Amman stock market. The empirical findings of the study suggest that the reliability of the AIS is based on the implementation of SysTrust's framework has a significant and positive relation to business performance and the quality of financial reporting significantly mediate the relationship.
\end{abstract}

Keywords: reliability of AIS, quality of financial reporting and business performance

Paper type Research paper

\section{INTRODUCTION}

Prior researches have shown that information system adoption did increase companies' performances and operations efficiency, especially in big companies (Saira $e t$ al., 2010). An AIS is a tool which, when incorporated into the field of Information and Technology systems (IT), were designed to help in the management and control of topics related to companies' economic-financial area (Salehi et al., 2014). The application of 
such information systems (IS) is mainly justified by the need to improve and bring efficiency into being; a fact evidenced by most researchers. At the scale of importance, the performance of accounting information systems is prioritized highly and this is mainly led by increased competition and revolution of the business environment at various levels, especially on the level of decision-making, since such systems are adopted in such a way that is designed for aiding in decision-making and enhancing an organization's competitive status. The ultimate aim of building data information systems, as indicated by Al-Dmour, et al., (2016), is to avoid risks at levels of decision-making. Thus, such systems are devoted to processing data and transforming it into accounting information according to the users' needs. Financial and accounting processes at organizations, which include advanced levels of using information technology, lead to more research and greater concerns related to risks, control and audit of the Accounting Information Systems (AIS). Material misstatements in financial reporting might be brought about by risks and vulnerabilities of Accounting Information Systems. Such risks, according to Klamm and Watson (2009), have mostly negative effects on integrity, accuracy, reality and availability of financial reports. Irrespective of their size, business companies today must consider the reliability and security of systems more than ever before.

System reliability in administration primarily guarantees the solidity of data and accounting framework. However, an unreliable system can exhibit a number of side effects as mentioned by Menna et al. (2016), such as regular system disappointments and accidents that deny inner and outside clients' access to key system administrations; failure to prevent unauthorized access to the system, making it vulnerable to viruses, hackers and loss of data confidentiality; loss of data integrity including defiled, inadequate and invented information, and genuine support issues bringing about unintended negative reactions from system changes, such as loss of access to system administrations, loss of information privacy or loss of information trustworthiness. Thus, to overcome such threats related to applying IT, the American Institute of Certified Public Accountants (AICPA) and the Canadian Institute of Chartered Accountants (CICA) established a new assurance service called SysTrust, whereby a public accountant can write about the adequacy of controls over the reliability of a system (Amin and Mohamed, 2016; Pathak and Lind, 2002). The reliability of financial data reporting relies mainly on accounting information systems and internal controls that positively affect financial reporting (Daneila, et al., 2013). Potentiality of error in reporting is related to weaknesses of internal control, namely the supervision of the accounting information system (Ricchiute, 2006). Further, the need of internal control is to produce reliable financial statements through supervision of the relevant accounting system (Ramdany, 2015). In terms of 'quality', Topash (2014) argues that maintaining characteristics of any accounting information system relies on a welldesigned internal control system. 
Studies that emphasize the necessity and importance of the internal control system in the accounting system are increasingly being acknowledged (Zulkanian, 2009). Al-Qudah and Ahmed (2011) suggested a significant impact on the company's internal control AIS in creating accuracy, updated, comprehensive and comparative data. One of the internal control objectives in the IT environment is to obtain financial statements of high reliability and to provide an adequate and appropriate evidence to attain the goals of the organization (Al-Laith, 2012). Recently, the assessment of the effect of the internal control of AIS on the quality of financial reporting has received great attention by academic and professional accountants (Ramdany, 2015). They had much concern about answering the question whether the reliability of internal control will lead to systematic improvements in the quality of financial reporting. In addition, studies on the SysTrust service engagement as an internal control method for assuring reliability in the professional accounting literature are primarily devoted to explaining the background and purpose of this service and its potential demand (Al-Dmour et al., 2017; Joseph 2009). Furthermore, examining the reliability of the accounting information system remains under-researched as the majority of such studies have concentrated on the status of the AIS adoption and its applications (Iceman and Hilson, 2012). Specifically, it is noticeable that the effect of reliability of internal control of the AIS on the quality of financial reporting has not received much attention.

In fact, there has been relatively little business-oriented research on the reliability of the AIS in non-western countries. The Accounting Information Systems' researchers can and should employ their knowledge of both technology and business to fill this void. Moreover, there is no clear empirical evidence on the extent of the effect of reliability of the AIS on financial reporting quality and business performance in developing countries' environments. Thus, the question of whether the reliability of internal control of the AIS could lead to systematic improvements in the quality of financial reporting is still an open question. Given that most articles of AIS implementation have been based on cases in Europe and the US, cultural and legislation challenges, although complex, show some inconsistency. However, relatively few studies have been implemented outside of the most developing countries, such as in Jordan, which is a beachhead for new technologies and business practices in the Middle East and North Africa (MENA). Several authors state that within organizations, attention must be given to the accounting standards and laws of each country because they affect accounting management (Davila et al., 2004; Romney and Steinbart, 2017).

Jordan as in any other developing countries, financial reporting practices are more of a result of "different sources of accounting influence" (Bukenya, 2014) and the various legal requirements. The financial reporting in Jordan is regulated through the commercial 
laws. The Companies Law regulates all types of companies; the Banking Law regulates the banks, while the Insurance Law regulates the insurance companies. In the same context, the Securities Law regulates all companies' activities regarding listing and trading matters in the financial markets. According to the Companies Law No. 22 (1997), Jordanian companies are divided into General Partnership, Limited Partnership, Limited Liability Company, Limited Partnership in Shares, Public Shareholding Company. The securities of public shareholding companies can be listed and traded in Amman Stock Exchange and their minimum paid-in capital is 500,000 Jordanian Dinars (JD). According to the Companies Law No. 22 (1997), public shareholding companies are obligated to appoint an auditor. Duties are assigned to the Jordanian auditor according to the Companies Law - the major responsibility being to audit companies' accounts in accordance with the recognized auditing rules, the auditing profession's principles and its scientific and technical standards. Moreover, an auditor is to review the financial and administrative by-laws of the company and its internal financial controls, to ensure their suitability for the company's business and the safeguarding of its assets. Accordingly, auditors in Jordan are responsible for assessment of companies' internal controls, in addition to undertaking the appropriate substantive tests. In accordance with Companies Law No. 22 (1997), all public shareholding companies are required to prepare and issue their annual audited financial statements - their balance sheets, income statements, and cash flows statements - within three months from the end of the company's fiscal year. Further, each public company is to prepare and issue its semi-annual financial statements, certified by the company auditors within 60 days from the end of the half-year period.

The present study has, therefore, come to bridge these gaps by examining the reliability of the AIS, based on the context of SysTrust's framework (principles \& criteria) and its relationship with quality of financial reporting and business performance through an integrated approach. The study aims not only to overcome the limitations of the previous studies, but also to improve the understanding of the importance of the reliability of the AIS process in the environmental context of Jordanian business culture as a developing country. Moreover, a review of the literature sheds light on the fact that reliability research is still fragmented, and that no comprehensive framework currently exists.

\section{THEORETICAL BACKGROUND and LITERATURE REVIEW}

\section{The Reliability of Accounting Information System}

The SysTrust service framework is an assurance service that was jointly developed by the American Institute of Certified Public Accountants (AICPA) and the Canadian Institute of Chartered Accountants (CICA). It is designed to increase the comfort of 
management, customers, and business partners with systems that support a business or particular activity. SysTrust is a type of assurance service performed by a licensed CPA or CA to independently test an organization's system and to offer assurance on the system's reliability. The intent is to enable those who use or rely on the system including the company itself, its partners, and customers to gain trust and condense in the system (AICPA/CICA, 2017; Bedard et al., 2005). Unlike COCO and COBIT, Trust Services framework was specifically designed for independent auditors to give an audit opinion as to whether the controls around the system were sufficiently effective to deem the system as "reliable". SysTrust initially began as a distinct standard (separate from WebTrust). In 2003, the two standards, SysTrust and WebTrust, were amalgamated into a single standard. However, practitioners can now draw on the relevant principles and criteria from the Trust Services Principles and Criteria framework and give a SysTrust opinion. The standard in its entirety consists of 5 principles, 4 control layers, and 139 criteria in total (AICPA/CICA, 2013). Depending on that assessment of the reliability of a system, a set of principles and criteria exists which are classified into five categories that are mainly relevant to systems' reliability and the reliability of an organization's financial data reporting as follows (AICPA, 2017):

1. Availability: Agreed and committed system and information thereof that are used for operations (legal obligation).

2. Security: Protected systems against unauthorized access - physically and logically.

3. Confidentiality: Confidential information that is protected as committed to or agreed

4. Processing Integrity: Processing data accurately, fully, in due timing and exclusively with proper authorization.

5. Privacy: Gathering, usage, disclosure, maintenance of personal information and its protection from unauthorized disclosure in accordance with internal policies and external regulatory requirements.

According to the AICPA, SysTrust is an assurance service that independently tests and verifies a system's reliability. The AICPA succinctly describes the overall purpose of SysTrust in the following way: Developments in information technology provide far greater power to companies at far lower costs. As business dependence on information technology increases, tolerance decreases for systems that are not secure, and these systems become unavailable when needed and unable to produce accurate information on a consistent basis. An unreliable system can cause a chain of events that negatively affect a company and its customers, suppliers, and business partners (Al-Dmour et al., 2017) 
This assurance service is distinct from reporting on internal control over financial reporting, which was established in 1993 by the AICPA and is described in SSAE No. 6.5 The latter service is limited to internal controls related to financial reporting and typically uses the criteria established in COSO, Internal Control: Integrated Framework. As such, it does not address the reliability of information systems designed for the broader decision needs of management and external users, who may need online access to real-time, updated and accurate information. In contrast, the new SysTrust assurance service relates directly to the overall reliability of a system, regardless of the type of information processed by the system. As such, the system may include financial and nonfinancial information that is critical to management and external users. Martin, (2005) also found the Trust Services framework to be a much more focused framework to work within the context of a SOX engagement and due the Trust Services "focus on the controls that are in place to ensure the company's systems carry out business processes reliably". He also found that the "Trust Services' illustrative controls are detailed enough to help management identify the controls that exist and those that are mis sing." A reliable system is the one that works without material errors, fault, or failure during a specified time in a specified environment. As for the symptoms of unreliable systems, they include frequent system failures and accidents that prevent users from accessing essential services, failure to prevent unauthorized access to the system, which makes it vulnerable to viruses, hackers and loss of data confidentiality, loss of data integrity, including corrupted, incomplete and fictitious data, and serious maintenance problems resulting in unintended negative side effects (Boritz et al., 2000).

The implementation of the SysTust's framework has two important potential advantages: (i) Enhancing the confidence of a broad audience (management, boards of directors, customers, and business partners) regarding the reliability of information systems; (ii) Providing accounting professionals with the ability to leverage their existing skills to fulfil the needs of the systems assurance marketplace. Based on these potential benefits and the increasing dependence of companies on information technology, the profession expects that SysTrust engagements will contribute to the demand for trust services, as well as other assurance services. Through the WebTrust and SysTrust services, companies have the ability to establish their credibility and build confidence with important end users (Pugliese and Halse, 2000; Al-Dmour et al., 2017).

Users of Sys Trust would be interested in a systems' assurance examination for some of the following reasons: (i) Internal and external users can lose access to essential services because of system failures and crashes; (ii) Systems can be vulnerable to viruses and hackers because of unauthorized system access; (iii) System failure can result in loss of access to system services or loss of data confidentiality or integrity; and (iv) Negative 
publicity in the wake of high-profile system failures can undermine customer and investor confidence. The AICPA Assurance Services Executive Committee (ASEC) has developed a set of principles and criteria (trust services' principles and criteria) to be used in evaluating controls relevant to the security, availability, and processing integrity of a system, and the confidentiality and privacy of the information processed by the system. In this document, a system is designed, implemented, and operated to achieve specific business objectives (for example, delivery of services, production of goods) in accordance with management specified requirements (AICPA, 2010).

\section{LITERATURE REVIEW}

Hoitash, et al., (2009) state that the value of internal control influences operational performance through information reliability and operational effectiveness. Computerized internal controls have effects on the value of internal controls and performance of operations. The usage of new information technology means computerized controls should be built it into the AIS. However, Ejoh and Ejom (2014) in their study revealed that there is no significant relationship between internal control activities and financial performance. Toposh (2014) suggested that other qualitative characteristics of accounting information can likewise be kept up if there is a sound internal control framework in an organization. Internal controls are methods set up to secure assets, guarantee reliable accounting reports, urge efficiency and encourage adherence to organization policies. Internal controls are fundamental to accomplish a few objectives like proficient and efficient direct of accounting exchanges, protecting the assets in adherence to management policy, prevention of error and detection of error, prevention of fraud, avoidance of misrepresentation and location of extortion and guaranteeing exactness, fulfilment, and detection of fraud and ensuring accuracy, completeness, reliability and timely preparation of accounting data. If good internal control exists in any organization, management can use information with greater reliance to maintain their business activities properly which provides AIS. But if the internal control is not strong, management cannot achieve its goal. The study by Topash (2014) likewise found that the accompanying criteria or indicators should be available in any accounting information system for it to be productive in any organization which is cost effective, has great documentation, a presence of legitimate safety efforts, a free inward and outward review, a separation of other operations from accounting, and effective internal control. In a similar vain, Daneila (2013) stated that accounting information systems and internal controls have a positive relationship to the financial reporting to produce reliable financial statements.

Furthermore, Ricchiute (2006) and Joseph et al. (2009) indicated that internal control weaknesses in overseeing the accounting information system will affect the likelihood that a material error in data reporting. Internal control is needed to oversee the 
accounting system that can produce reliable financial statements (Daigle, 2005; Konrath, 2005). AIS and internal control are an integral part in generating quality financial reports that can be used as a foundation for management decision-making and the parties concerned. Research conducted by Costello and Wittenberg (2010) revealed that if the company's internal control AIS is not reliable then the investors will not use the financial statements generated by the company in its decision-making. Also, Kim et al. (2011) claimed that internal control weakness which leads to lower internal control quality will increase the cost of financing in bank loans. Li states that the higher internal control quality can reduce the cost of finance, detect and prevent fraud and errors, safeguard assets, encourage employees to follow policy, comply with legal regulation and other benefits for the firms ( $\mathrm{Li}, 2017)$.

Explaining variation in a firm performance is the central focus of much of the business literature. A large part of the literature and previous studies tried to examine the quality of financial reporting and its effects on the subsequent performance of a company. For example, Ahmed and Duellmand (2011) and Martinez-Ferrero (2014) in their study found that there was a positive effect for the quality of financial reporting on the overall higher performance of the company. Due to the fact that the quality of the financial report guarantees and enforces the company to present good and accurate information which, in turn, reduces the mystery and the conflict in information provided for both shareholders and stakeholders and other market participants interested in this report. The integrity and reliability of data produced by organizational information systems are critical, not just for the production of reliable financial reports, but also for overall business success (Krishnan et al., 2006).

Other benefits of having high-quality information from financial reporting are mentioned in Lambert et al. (2007). He clarified that the high-quality information guarantees the reduction of information risk and liquidity. Other opinions are mentioned in Chen et al. (2011): it reduces the manager's authority and power in making decisions for their own interests, and guides them to make appropriate and efficient investment decisions. Rajgopal and Venkatachalam (2011) added that the high-quality financial reporting reduces the lack of equivalence and the asymmetric information that arises from conflicting agencies. It also helps market agents to get a full understanding about all company operations and activities by reducing the ambiguity that surrounds some events (Ostadi and Abedini, 2015). Lambert et al. (2007) mentioned that quality of accounting information has critical effects on market participants' perceptions about the distribution and decisions related to the company's future cash flow. On the other hand, Chen et al. (2011) found that both banks and governments can get benefits of having the high-quality financial reporting, because it has a positive effect on a private firm's investment 
efficiency and financial performance which, in turn, increases the tax payment and lending from banks. Visser and Erasmus (2009) put it that an ICS contains certain control activities, including policies and procedures with regard to approval, authorisation, verification, reconciliation, review of operational activities, safeguarding of assets, and segregation of duties. Muraleetharan (2013) in his study on control activities and performance of organisations established a positive relationship between control activities and performance.

Recognizing the critical impact of the quality of financial reporting upon an investment decision, developing countries and countries with economies experiencing significant change are attaching greater significance to transparency and reliability in corporate accounting and reporting. They are making efforts to strengthen the different components of accounting infrastructure in their respective jurisdictions so that financial resources can be assembled and utilized all the more effectively (IFRS, 2008). Financial reporting practices are more of a result of 'different sources of accounting influence' and the various legal requirements (Bukenya, 2014). Thus, in line with the International Financial Reporting Standards (IFRS, 2010) and according to the Companies Law No. 22 (1997), public shareholding companies in Jordan are obligated to present a reliable internal control of the accounting information system and adequate annual financial reporting. Probably, the toughest regulations are in the USA where the Sarbnes Oxly Act since 2002, especially section 404, requires public companies to include in their annual reports an assessment by management of their internal controls over financial reporting. This incorporates a statement of the management's obligation for submitting and maintaining an adequate internal control, an appraisal of the adequacy of those controls as of the end of the most recent fiscal year, a statement identifying the framework that was utilized to assess those controls and a statement that the external auditor issued an authentication report on the management's internal control evaluation. The rules don't mandate the utilization of a specific framework; yet an appropriate one must: be free of predisposition, allow sensibly reliable subjective and quantitative assessment, incorporate all relevant factors that might adjust a decision about the effectiveness of the internal controls and be relevant to an evaluation of internal control over financial reporting (Kewo and Afiah, 2017).

Proposed benefits from the use of Systrust service include improved confidence in the systems of both business partners' and one's own internal systems, avoiding problems of system development (McPhie, 2000) and reducing the cost of business interruption insurance (Pugliese and Halse, 2000). The literature suggest that SysTrust provides a good framework for auditing internal systems (Boritz et al., 2000) and restructuring systems controls and procedures (Trabert and Mackler, 2001), and sets a standard for structuring information technology outsourcing agreements (Boritz et al., 
2000). Boritz and Honton (2002) report that SysTrust assurance significantly increased user comfort levels with the reliability of the information technology of a service provider, as well as the possibility that users would recommend contracting with the service provider. Even though the possible benefits of trust services to clients have been focused on in the literature, there is a lack of experimental evidence to support the debate that the existence of a trust service assurance report gives a precise sign of systems quality.

Therefore, any company's management should apply an adequate and strong internal control framework for assuring the reliability of the AIS process over the quality of financial data reporting and other reports. According to Daneila (2013), the weak internal controls of AIS will cause an error misstatement in the financial data that cannot be anticipated and potential investors will trust and invest into a company if the business's practice is not transparent. After reviewing the previous studies, in this specific area of research, relating to reliability of CAIS control systems, quality of financial reporting and business performance, it can be observed that there are not enough empirical studies available, and this could be due to the fact that this area of research is reasonably new. In addition, many of the studies in this subject are administered on a small level and connected with combined studies from the fields of business management, computer science, and sometimes engineering. They are often in the form of reports or descriptive studies, and rarely experimental. To summarize, there is a lack of academic literature on the issues of SysTrust assurance service as an internal control for assuring the reliability of AIS and its influence on the quality of financial and business performance. It should also be noted that some of the investigations are conducted in isolation, without benefit from the experience of findings from other studies. Therefore, this study has come to fill this gap and to empirically examine and validate the relationship among these major constructs (reliability of AIS, quality financial reporting and business performance) through an integrated approach

\section{The Study's conceptual framework}

Theoretical background and empirical studies on the SysTrust's framework as an internal control for assuring the reliability of AIS as well as the relevant theoretical literature on business performance and the quality of financial reporting were reviewed and integrated to develop a conceptual framework to guide this study. The proposed framework has tied together the components of SysTrust's service framework (i.e., principles and criteria) which are postulated to assess the reliability of AIS process and its influence on the business performance. These major components are mainly derived from five principles of SysTrust's framework: availability, processing integrity, privacy, security and confidentiality. According to the existing frameworks on IS and accounting management (Dehning and Richardson 2002, DeLone and McLean 2003, Gable, et al., 
2008), business performance as well as the quality of financial reporting could be a function of the quality of internal control of accounting information system. Understanding of the critical components that influence data quality reporting in AIS could assist organizations to improve their AIS data quality. Inadequate financial reporting quality might cause a lot of business operations run inefficiently and less in accordance with the demands and needs of the stakeholders. Supposedly, in order to anticipate these conditions, businesses must have reliable software and databases in generating quality information.

However, the effect of implementation of SysTust's framework as an internal accounting control method for assuring the reliability of AIS has been given little attention in previous studies. The integrated framework proposed is used here to investigate whether the business performance (i.e. financial and non-financial indictors) is a function of the implementation of SysTust's framework as an internal control system of accounting (i.e., availability, security, processing integrity, confidentiality and privacy) through the mediating role of quality of financial reporting. The quality of financial reporting was conceptualized by the IASB's framework (2010) fundamental qualitative characteristics (relevance, faithful representation, comparability, understandability and timeliness). The expected relationships among these constructs are illustrated in Figure 1.

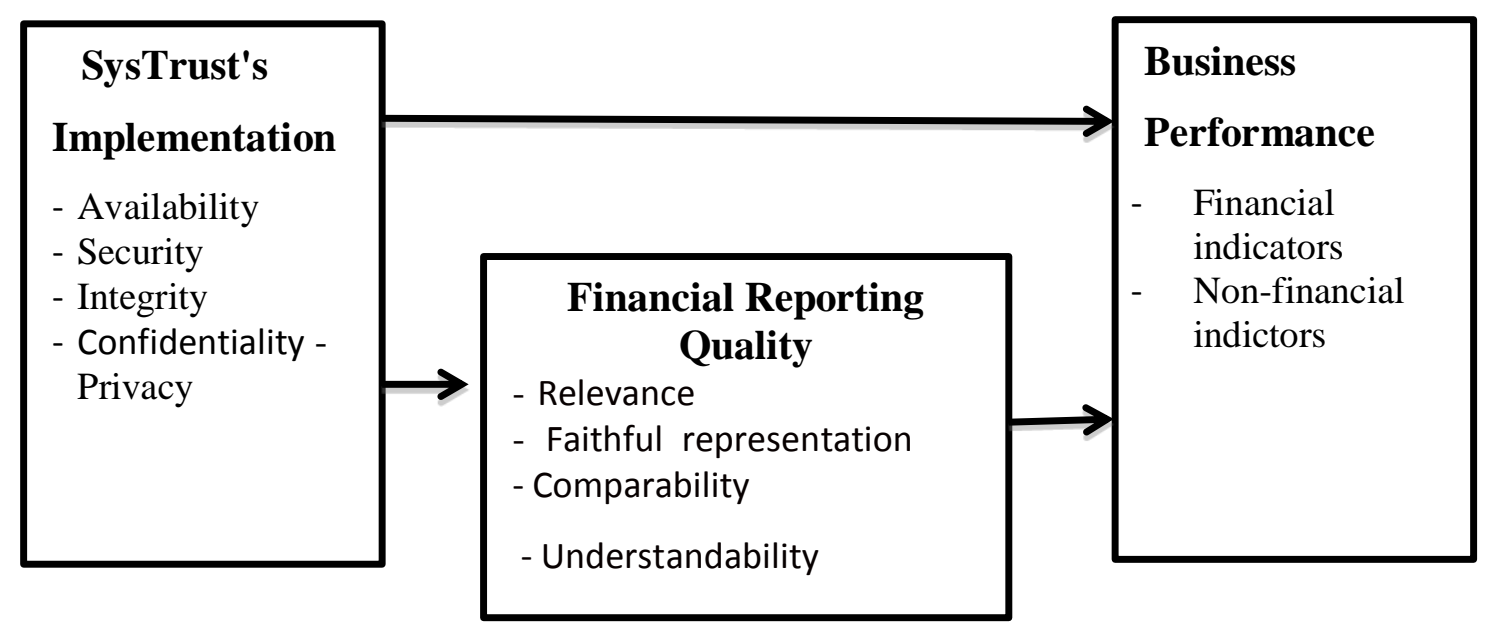

Figure 1 Study's Conceptual framework 


\section{The Business Performance (financial and non-financial indicators)}

Organizations today are struggling aggressively to cope with all the changes surrounding them by enhancing their business performance through the competitive advantage they develop (Kagaari, 2011; Masa'deh et al., 2015). Explaining variation in firm performance is the central focus of much of the business literature. Researchers have always looked at business performance as the ultimate goal concerned with almost every area in management. This is because business performance allows researchers to evaluate organizations, their actions, and environments and compare them to those of their competitors (Richard et al., 2009; Santos and Brito, 2012). Most literature suggests that when it comes to business performance, researchers find it difficult to define, conceptualize and measure this concept (Alrowwad; 2017; Taghian et al., 2015). Some authors (Chow and Steve, 2006; Marie et al., 2014) indicated that although financial measures are important, they are not sufficient for a good performance evaluation system. The system should further include non-financial measures of performance. According to Dossi, \& Pateli (2010), appropriate performance measures are those which enable organizations to direct their actions towards achieving their strategic objectives to the opportunities and threats in the environment.

Despite the dearth of research available on separate performance dimensions, the choice of adequate performance measures is likely to be influenced by several contextual factors identified in the contingency-based research (Chenhall, 2005; Henri et al., 2014). In response to the debate relating to the advantages and disadvantages of considering financial or non-financial performance measures and the appropriate choice of measures, some empirical evidence indicates that financial and non-financial measures are not substitutes, but that non-financial measures are used as supplements to financial measures (Al-Thuneibat, et al., 2016 and Kinyua et al., 2015). Yet effective frameworks of performance measures that integrate both financial and non-financial measures have been developed. Such frameworks are based on the fact that management accounting information systems cannot solely be based on financial information. A combination of financial and non-financial information is needed to give a more balanced representation of the overall performance of the organization. An examination of the performance measurement systems in the literature demonstrates that many management accounting scholars (Harrison et al., 2012; Hla and Teru, 2015; Taiwo and Edwin, 2016) incorporated non-financial performance measures as an essential part of the management information system.

As far as operationalization of performance measures is concerned, apart from the dimensionality, another challenge is the selection of the kind of measure, i.e. objectives subjective measures. Several scholars have argued the necessity to use subjective 
performance measures as a substitute for objective measure (Vij and Bdi 2016, Masa' deh, et al., 2015, Wall et al. 2004 and Kim et al., 2004). The use of subjective measurements for business performance is made more necessary by the relative difficulty of gathering objective financial data. Either these types of data are unavailable, or they are obscured or manipulated by managers eager to protect their firms' reputations or avoid personal or corporate taxes. In addition, subjective measures would allow comparison across firms and contexts, such as industry types, time horizons, cultures or economic condition (Vij and Bdi 2016). Indeed, it could be a good alternative if the measures focus on the firm's current condition and the objective data may not be compatible with the intended level of analysis (Wall et al., 2004). Furthermore, subjective scale measures have been commonly featured in the business literature and supported it as a valid and reliable method (Masa'deh, 2015). Therefore these results maintain that subjective measures can be used to assess the firm's performance and probably lead to convergent results of different magnitudes. In the validation issue, for example, Dess and Robinson (1984) state that subjective measurements are strongly correlated with objective measurements in terms of the absolute changes in return on assets and sales, over the same time period. For example, the result of the correlation $(r)$ between objective and subjective measures to total sales gives a value for $r$ of .80, and to ROA gives a value for $r$ of .79. This supports the validity of the performance evaluation through subjective measures

Based upon these above arguments, this study will use subjective measures for both dimensions of business performance (financial and non-financial) since recording standards of objective indicators vary across firms and industries. The respondents will be asked to point out the degree of their business performance relative to industry /service sector average using a seven-point Likert scale with anchors 'very low' to 'very high. Comparing the firm's performance relative to its industry or service average is considered reasonable and preferable when researchers interested in measuring firm performance across industries with subjective indicators (Santos and Brito, 2012). The items making up this scale were divided into two subscales: financial performance (e.g.: return on assets (ROA), return on equity (ROE), sales growth, market value, and profitability growth), and non-financial performance (customer satisfaction, employees satisfaction, shareholder satisfaction, environmental performance, and social performance). These most common measures were selected in order to facilitate the comparison with the findings of prior studies in this filed.

\section{Qualitative Characteristics of Financial Data Reporting}

Kieso et al. (2016) defines financial reporting as the process of presenting business financial statements in the form of a financial report for both internal and external parties related to the company. Ramdany (2015) proposes the same concept by adding that it also includes initially recording and rating all business activities, especially financial 
transactions, then comes the reporting phase of these activities in order to present them for the related parties. Elliot and Elliot (2017) implied that financial reporting relates to the process of providing the current situation of the business' financial status represented by the financial information to the related parties, (such as internal and external parties) from the onside to the current and potential investors from the other side, who can depend on this information to assess business performance, and then make the appropriate decisions. The main objective of financial reporting is to provide information concerning economic entity, primarily financial in nature, and useful for economic decision-making (Cao et al., 2012; IASB, 2008; Yurisandi and Puspitasari, 2015).

Financial reporting provides information about the management's stewardship: the entity's assets, liabilities, equity, income and expenses (including gains and losses), contributions by and distributions to owners as well as cash flow (Beest et al., 2009). This information is usually in the form of annual financial statements such as: the statement of financial position; the income statement or statement of comprehensive income; a statement of cash flows; and a statement of changes in equity as well as notes to the accounts (IASB, 2008; 2010). To enhance reliability and confidence in the minds of the users, these reports are subjected to scrutiny by external auditors. However, the spate of financial scandals in recent times has cast serious doubt on the quality of audited financial reports circulating in our corporate environment.

Thus, the concept of quality financial reporting has received great attention by accounting scholars around the world. However, researchers, practitioners or regulators are in disagreement as to a clear definition of what constitutes 'quality financial reporting'. Pomeroy and Thoronton (2008) and Miettinen (2011), for instance, require audit committees and auditors to discuss the quality of the financial reporting methods of the company, and not just their acceptability. But the Act did not define what constitutes 'quality' in financial reporting. The IASB (2008) has, however, provided a working definition of quality financial reporting. The Board in its conceptual framework defines quality financial reporting as that which meets the objectives and the qualitative characteristics of financial reporting (Beest et al., 2009; IASB, 2008). Meanwhile, Kieso et al. (2016) stress that in order to have a quality financial report, the information should be relevant by having the ability to make different decisions, valid through producing a predictive value which is the input for investors in predicting future conditions; it also has to have a value of confirmation which helps the user to confirm or correct information of previous expectations. An honest presentation or faithful representation of information is also considered to be an important variable for ensuring a quality financial report which means the complete presentation of all necessary information. The next requirement is neutrality, which means that the information presented by the company only caters to 
certain parties over the interests of other parties. The last condition is presented in honest accounting, which means that information is error free.

Evidence from previous literature ensures that the judgment of the quality of a financial report is not easy and a complex activity, because it is connected with the perceptions and decisions of individual users. Therefore, various types of measurement methods have been developed to assess and evaluate the quality of financial reporting (e.g. Clor-Proell et al., 2014; Müller, et al., 2015). However, most of researchers depend on quantitative measures and indicators such as earnings quality and value relevance proxies for assessing information quality, because these measures focus on specific attributes of financial reporting information. Barth (2014) and Ahmed, et al., (2013) prefer this method because it concentrates on the decision usefulness of the information given in a financial report, and the quality metrics used at this method are generally more reliable than other methods. Other researchers such as Mbodo and Ekp (2016), P־aşcan and Ţurcaş (2012), Tasios and Bekiaris (2012) and Yurisandi and Puspitasari (2015) also stress the importance of qualitative characteristics for assessing information quality provided by financial reports, as well as the recommendations of CF (IASB, 2010). In addition to the evidence from other researches, they discovered that qualitative characteristics can indeed be operationalized.

Developing high-quality accounting standards has been investigated commonly and internationally by many works and researches. One of these issues, presented in May 2008 by FASB and the IASB, involves an exposure draft called 'An Improved Conceptual Framework for Financial Reporting' (IASB, 2008; 2010). This implies that the company should give more importance and focus on qualitative characteristic objectives beside the accounting principles in order to enhance the effectiveness and the quality of financial reporting process, which is also appropriate for decision makers, and leads to accurate, useful and constitute decisions (FASB, 1999; 2008). According to Mbodo and Ekp, (2016), the 'Qualitative Characteristics Model' for measuring is the most recent model for assessing the quality of financial reporting. This model examines the level of decision usefulness of financial reporting information by operationalizing the qualitative characteristics of financial reports. Jonas and Blanchet (2000) pioneered the use of this model in assessing the quality of financial reporting. They developed questions that were germane to the separate qualitative characteristics of financial reporting as stipulated by the FASB (1980) and IASB (1989). The model was adopted by many researchers (Gaynor et al., 2016; Mbodo and Ekpo, 2016). The major advantage of this model is that it provides a direct measure of financial reporting quality and covers all aspects of financial reports including both financial and non-financial information. Based upon the above discussion, this study has adopted IASB's framework (2013) for measuring the quality of financial reporting. 
The framework listed these attributes as relevance, faithful representation, comparability, understandability and timeliness. It has been argued that the framework which uses the qualitative characteristics approach in measuring quality financial reporting provides a direct and better measure of financial reporting quality (Mbodo and Ekp, 2016; Tasios and Bekiaris, 2012). In spite of the obvious merits of this framework especially the fact that it aligns strongly with the International Financial Reporting Standards (IFRS), many researchers in recent studies still prefer to use the indirect method, especially discretionally accrual (earnings management) as a proxy for financial reporting quality. This, perhaps, is due to the difficulty in operationalizing the qualitative characteristics (Beest et al., 2009). Indeed, studies which attempt to operationalize the qualitative characteristics in financial reporting are very few in Jordan. This study, therefore, contributes towards filling this gap. Based on these facts, the current study will depend on the seven-point rating scales of qualitative characteristics mentioned on ED (IASB, 2008) to assess financial reporting quality. To assure the internal validity of these items, the quality measures are based on prior empirical literature (Mbodo and Ekp, 2016; Tasios and Bekiaris, 2012). This type of measure is employed in this study in order to facilitate the comparison between the findings of using it and the findings of previous works in this field. Here are some brief explanations of these qualitative characteristics:

1. Relevance: IASB (2008) defines relevance as the capability of making a difference in the decisions made by users in their capacity as capital providers. Relevance is usually operationalized in terms of predictive and confirmatory value (Beest et al. 2009)

2. Faithful Representation: Faithful representation means that all information listed in financial report must be represented faithfully, IASB, (2006) stated that in order to accomplish this all information and economic phenomena listed in annual reports must be complete, accurate, neutral, and free from bias and errors.

3. Understandability: Understandability is referred to the process of classifying, characterizing, categorizing, then presenting the financial information clearly and concisely, for (IASB, 2008) understandability means assuring financial information transparency and clearness, this process needs relating to some financial measures.

4. Comparability: Comparability means the ability that the information has in explaining and identifying similarities in and differences between two common sets or transactions of economic phenomena (IASB, 2008: 39). According to the ED, comparability could be arrived by attaining consistent information by companies, this could happen by enforcing the company to use the same accounting policies and procedures, either from period to period within an entity or in a single period across entities (IASB, 2008: 39). 
5. Timeliness: The last enhancing qualitative characteristic discussed in the IASB (2010) conceptual framework is timeliness. The framework defines timeliness as having information available to decision makers before it loses its capacity to influence decisions (IASB, 2010). In specific terms, timeliness relates to the decision usefulness of financial reports. It refers to the time it takes to reveal the information in annual reports. It is usually measured in terms of the number of days it takes for the auditor to sign the accounts after book-year end.

4. Study Hypotheses: Based upon the study's conceptual framework, the study's hypotheses are formulated and proposed as summarized below:

Ho (1): The reliability of AIS will have a significant relationship with the business performance.

Ho (2): The reliability of AIS will have a significant relationship with the quality of financial reporting.

Ho (3): The quality of financial reporting will have a significant relationship with the business performance.

Ho (4): The quality of financial reporting is significantly mediating the relationship between the reliability of AIS and the business performance.

\section{STUDY METHODOLOGY}

\section{Study Population Characteristics}

To obtain the empirical data needed to validate the study's conceptual framework and examine the research hypotheses, a self-administered questionnaire was used to collect the required data from the key respondents. The target respondents were the accounting and auditing managers in the public listed companies in Amman Stock Market (2016). A total of 328 self-administered questionnaires were distributed to the respondents by e-mail, postal, and hand from and the response rate was $73 \%$ after a period of sixteen weeks and two follow-up reminders. Table 1 demonstrates the demographic characteristics of the study's respondents.

Table 1: Demographic Characteristics of the Study's Respondents

\begin{tabular}{|l|c|c|}
\hline \multicolumn{1}{|c|}{ Demographic Characteristics } & Number & Percentages \\
\hline Type of Sector & & \\
\hline Service & 162 & 0.68 \\
\hline Industries & 77 & 0.32 \\
\hline Size: Number of employees & & \\
\hline$>100$ employees & 92 & 0.38 \\
\hline
\end{tabular}




\begin{tabular}{|l|c|c|}
\hline$\leq 100$ employees & 147 & 0.62 \\
\hline $\begin{array}{l}\text { Experience: Number of years in } \\
\text { business }\end{array}$ & & \\
\hline$>10$ years & 96 & 0.40 \\
\hline$\leq 10$ years & 143 & 0.60 \\
\hline Total & 239 & $100 \%$ \\
\hline
\end{tabular}

\section{Measurement Instrument}

The survey instrument is based on constructs validated in prior research, standardized and revised to the context in this study. In this survey, some variables are factual (for example, companies' demographic information such as the type of sector, number of employees, number of years in business), whereas others are perceptual (for instance, SysTrust's principles, financial reporting quality and business performance, etc.). The dependent and the mediating variables (i.e. the financial reporting quality and business performance) and the independent variables (the components of SysTrust's framework) were measured using a seven-point Likert scale. The questionnaire's content (constructs and measures) were mainly selected from the AICPA framework (2017), the IASB's framework (2010) and prior relevant studies and they were modified to the practice of Jordanian public listed companies' culture context based on the results of a pilot study and feedback from five professional academic staff in this field.

\section{DATA ANALYSIS TECHNIQUES}

\section{Factor Analysis Results}

The main purpose behind the use of factor analysis techniques is to reduce the large number of variables that underlie each construct of both dimensions (i.e. SysTrust's components, quality of financial reporting and business performance) into orthogonal indices for further analysis by the regression analysis. Furthermore, by employing the principle component analysis techniques, it may be possible to explore the patterns of factors that underlie each major construct. It was considered an appropriate method to overcome the potential problems of multicollinearity among the variables that pertain to each construct.

Table 2 Main Factors Underlying Each Construct of the Study

\begin{tabular}{|l|ll|l|l|l|}
\hline \multicolumn{5}{|c|}{ Factors Underlying the Reliability of AIS: Eleven Factors (1) } \\
\hline Factors & $\begin{array}{l}\text { No. of } \\
\text { items }\end{array}$ & Eigen value & Variance \% & Cumulative \% \\
\hline Availability
\end{tabular}




\begin{tabular}{|c|c|c|c|c|}
\hline $\begin{array}{l}\text { AIS availability } \\
\text { Policies }\end{array}$ & 5 & 3.264 & 25.109 & 25.109 \\
\hline $\begin{array}{l}\text { Recovery Disaster } \\
\text { Plan }\end{array}$ & 4 & 3.125 & 24.040 & 49.149 \\
\hline $\begin{array}{l}\text { Availability } \\
\text { Communication }\end{array}$ & 4 & 3.042 & 23.397 & 72.546 \\
\hline \multicolumn{5}{|l|}{ Security } \\
\hline $\begin{array}{l}\text { Logical Security } \\
\text { Access }\end{array}$ & 6 & 5.132 & 28.510 & 28.510 \\
\hline $\begin{array}{l}\text { Security Policies and } \\
\text { Communication }\end{array}$ & 6 & 4.772 & 26.511 & 55.021 \\
\hline $\begin{array}{l}\text { Physical Security } \\
\text { Access }\end{array}$ & 6 & 3.817 & 21.203 & 76.224 \\
\hline \multicolumn{5}{|l|}{ Integrity Processing } \\
\hline $\begin{array}{l}\text { Integrity Processing } \\
\text { Policies }\end{array}$ & 5 & 4.683 & 27.549 & 27.549 \\
\hline Data Transfer Control & 6 & 3.477 & 20.453 & 48.003 \\
\hline Output Control & 6 & 3.370 & 19.826 & 67.828 \\
\hline \multicolumn{5}{|l|}{ Confidentiality } \\
\hline Confidentiality & 12 & 7.621 & 63.505 & 63.505 \\
\hline \multicolumn{5}{|l|}{ Privacy } \\
\hline Privacy & 10 & 6.709 & 67.091 & 67.09 \\
\hline \multicolumn{5}{|c|}{ (2) Factors Underlying the Quality of Financial Reporting: Five factors } \\
\hline Relevance & 7 & 5.245 & 20.981 & 20.981 \\
\hline Understandability & 7 & 5.117 & 20.468 & 41.449 \\
\hline Faith representation & 6 & 4.793 & 19.174 & 60.623 \\
\hline Comparability & 5 & 3.944 & 15.775 & 76.398 \\
\hline Timeliness & 3 & 3.456 & 3.453 & 79.751 \\
\hline \multicolumn{5}{|c|}{ (3) Factors Underlying Business Performance: Two factors } \\
\hline Financial & 5 & 6.897 & 36.303 & 36.303 \\
\hline Non-financial & 5 & 6.527 & 34.354 & 70.657 \\
\hline
\end{tabular}

A pre-analysis was conducted to examine the appropriateness of the data for factor analysis, and then the results of the factor analysis were examined using multiple criteria, including eigenvalues, interpretability and internal consistency, as recommended by Hair et al. (2010). Therefore, the items determined to have eigenvalues greater than one and factor loadings less than .40 had little or no relationship with one another; hence, they were discarded (Hair et al., 2010). The results of the principle components analysis indicate that eleven factors can be extracted from the reliability of AIS; four factors from 
the quality of financial reporting and two factors from the business performance. In summary, based on the preliminary analysis, the evaluation of the data by factor analysis and reliability estimates indicated that all scale items were appropriate and valid for further statistical analysis. Finally, Cronbach's alpha reliabilities were examined for each variable. Each coefficient greater than .60 for adapted and .70 for existing scales was considered a reliable indicator of the constructs under study (Hair et al., 2010). The reliability analysis was carried out for each construct (reliability of AIS, quality of financial reporting and business performance). The resulted score ranged from .85 to .93 .

\section{The Extent of the Implementation of SysTrust's Service Principles}

The mean values, standard deviation and t-test are employed here to determine whether the main five principles of SysTrust's framework being implemented by public listed companies in Jordan. Findings shown in Table 3 indicate that the extent of SysTrust principles (together) being practiced is considered to be moderate (i.e. $74 \%$ or 5.20), since their mean are more than the mean of the scale, which is 4 (mean of the scale $=\Sigma$ Degrees of the scale $7=1+2+3+4+5+6+7 / 7=5.20$ ). This implies that there are some variations among shareholdings companies in terms of their level of implementations of SysTrust's framework (principles and criteria) and it might be due to their type of the business and the nature of audit IT control system.

Table 3: Thee Extent of the Implementation of SysTrust's Principles in Public Listed Companies in Jordan

\begin{tabular}{|l|c|c|c|c|}
\hline SysTrust Principles & Mean & Percentage & $\begin{array}{c}\text { Standard } \\
\text { deviation }\end{array}$ & Sig. (2-tailed) \\
\hline Availability & 5.1398 & 0.7342 & 0.86783 & 0.000 \\
\hline Security & 5.5559 & 0.7937 & 0.91053 & 0.000 \\
\hline Integrity processing & 5.2214 & 0.7459 & 0.76369 & 0.000 \\
\hline Confidentiality & 5.2184 & 0.7454 & 0.87010 & 0.000 \\
\hline Privacy & 5.2254 & 0.7464 & 0.91306 & 0.000 \\
\hline Average & 5.2214 & 0.7459 & 0.75279 & 0.000 \\
\hline
\end{tabular}

\section{Testing Hypotheses}

The multiple regression analysis technique was used to examine the first three hypotheses. Table 4 summarizes the results of multiple regression analysis, with the Fratio test, for the study hypotheses (Ho1, Ho2 and Ho3). The results indicate that each of these hypotheses is accepted at 0.000 level of significance. Accordingly, it may be concluded that there is a significant relationship between reliability of AIS, the quality of financial and business performance, and between the quality of financial reporting and 
business performance. These results empirically proved that the reliability of AIS has a positive direct impact not only the business performance but also on the quality of financial reporting.

Table 4: A Summary Result of the Multiple Regressions

\begin{tabular}{|c|c|l|l|l|l|l|}
\hline $\begin{array}{l}\text { Hypothese } \\
\text { S }\end{array}$ & Multiple R & $\begin{array}{l}\text { R. } \\
\text { Square }\end{array}$ & $\begin{array}{l}\text { Adjusted R } \\
\text { Square }\end{array}$ & DF & F & Sign \\
\hline Ho1 & $0.822^{\mathrm{a}}$ & 0.676 & 0.665 & 11 & 63.340 & 0.000 \\
\hline Ho2 & $0.751^{\mathrm{a}}$ & 0.564 & 0.550 & 11 & 67.650 & 0.000 \\
\hline H3a & $0.808^{\mathrm{a}}$ & 0.653 & 0.649 & 4 & 160.31 & 0.000 \\
\hline
\end{tabular}

To test the fourth hypothesis (Ho 4), a combination of simple and multiple regression analyses were conducted as proposed by Baron and Kenny (1986). The results of the regression tests can be seen in Table 5. It is worth noting that the Baron and Kenny (1986) model of mediation focuses on the unstandardized regression coefficients; therefore, the coefficients mentioned in the table below represent the unstandardized betas. In order to determine whether the quality of financial reporting acts as a mediator in the relationship between the reliability of AIS and business performance, the following rule should be followed: some form of mediation is supported if the effect of the expected mediator remains significant after controlling the independent variable. If the independent variable is no longer significant when the expected mediator is controlled, the finding supports full mediation.

If the independent variable is still significant (i.e. both the independent variable and the expected mediator both significantly predict the exists since reliability of AIS and quality of financial reporting both significantly predict business performance (p-values= 0.000). Furthermore, the strength of the independent variable in predicting the dependent should be reduced in the presence of the mediator variable in order to support partial mediation. In this case the unstandardized beta for the implementation of reliability of AIS was reduced from 0.66 to 0.21 which supports the condition for partial mediation. According to Baron and Kenny (1986), having a partial mediation model is more realistic in most social science research because a single mediator cannot be expected to completely explain the relationship between the independent variable and the dependent variable. 
Table 5: Regression Analysis for Mediation of Quality of Financial Reporting on Business Performance through the Reliability of AIS

\begin{tabular}{|l|c|c|c|c|}
\hline Variables & $\begin{array}{c}\text { Step 1 } \\
\text { Business } \\
\text { Performance }\end{array}$ & $\begin{array}{c}\text { Step 2 } \\
\text { Quality of } \\
\text { Financial }\end{array}$ & $\begin{array}{c}\text { Step 3 } \\
\text { Business } \\
\text { Performance }\end{array}$ & $\begin{array}{c}\text { Step 4 } \\
\text { Business } \\
\text { Performance }\end{array}$ \\
\hline (Constant) & -3.479 -** $^{*}$ & $-2.753^{* *}$ & $-1.173 \mathrm{E}-016^{*}$ & $-1.059^{* * *}$ \\
\hline $\begin{array}{l}\text { Reliability } \\
\text { of AIS }\end{array}$ & $0.660^{* *}$ & $0.522^{* *}$ & & $.201^{* *}$ \\
\hline $\begin{array}{l}\text { Quality of } \\
\text { Financial }\end{array}$ & & & $0.558^{* *}$ & $0.879^{* *}$ \\
\hline $\mathbf{R}$ & $0.702^{\mathrm{a}}$ & $0.786^{\mathrm{a}}$ & $0.790^{\mathrm{a}}$ & $0.801^{\mathrm{a}}$ \\
\hline $\mathbf{R}^{2}$ & 0.493 & 0.618 & 0.623 & 0.641 \\
\hline Adj. $\mathbf{R}^{2}$ & 0.492 & 0.617 & 0.622 & 0.639 \\
\hline F-value & 335.111 & 557.165 & 569.312 & 305.973 \\
\hline$* * \mathrm{p} \leq 0.00$ & & & &
\end{tabular}

Although Baron and Kenny (1986) provide an appealing approach to follow in order to determine the presence or absence of a mediation effect, it is considered necessary to conduct a formal significance test of the indirect effect if the Baron and Kenny criteria have been met (Preacher et al., 2008). This is important for two reasons. First, there are shortcomings related to the Baron and Kenny method. According to Baron and Kenny, it is possible to observe a change from a significant $\mathrm{X} \rightarrow \mathrm{Y}$ path to a non-significant $\mathrm{X} \rightarrow \mathrm{Y}$ when adding a mediator to the model with a very small change in the absolute size of the coefficient. This result may lead a researcher to erroneously conclude that a mediation effect is present (Type I error). Conversely, it is possible to observe a large change in the $\mathrm{X} \rightarrow \mathrm{Y}$ path when adding a mediator to the model without observing a change in statistical significance (Type II error).

This situation is likely to occur when large samples are employed as those are the conditions under which even small regression weights may remain statistically significant. Testing the hypothesis of no difference between the total effect (path c) and the direct effect (path c') more directly addresses the mediation hypothesis than does the series of regression analyses recommended by Baron and Kenny (1986). In the case of simple mediation, the indirect effect of $\mathrm{X}$ on $\mathrm{Y}$ through $\mathrm{M}$ is measured as the result of the $\mathrm{X} \rightarrow \mathrm{M}$ and $\mathrm{M} \rightarrow \mathrm{Y}$ path ab, which is equivalent to $\mathrm{c}-\mathrm{c}^{\prime}$ in most cases. Thus, a significance test associated with ab should address mediation more directly than a series of separate significance tests that do not directly involve ab (Preacher and Hayes, 2008). There are more statistically rigorous methods by which mediation hypotheses may be tested (Preacher et al., 2008). Baron and Kenny (1986) described a procedure developed 
by Sobel (1982) that assesses more directly the indirect effect of mediation. According to Preacher et al., (2008), the Sobel test is considered a superior test in terms of power and intuitive appeal. The Sobel test is performed by comparing the strength of the indirect effect of $\mathrm{X}$ on $\mathrm{Y}$ to the point null hypothesis that it equals zero. The indirect effect of $\mathrm{X}$ on $\mathrm{Y}$ in this situation is defined as the product of the $\mathrm{X} \rightarrow \mathrm{M}$ (path a) and the $\mathrm{M} \rightarrow \mathrm{Y}$ (path $b$ ), or $a b$. In most situations, $a b=c-c$ ', where $c$ is the simple (i.e. total) effect of $X$ on $\mathrm{Y}$, not controlling for $\mathrm{M}$, and c' is the $\mathrm{X} \rightarrow \mathrm{Y}$ path coefficient after the addition of $M$ to the model. Standard errors of $a$ and $b$ are represented, by $s_{a}$ and $s_{b}$, respectively. The standard error of the indirect effect $\left(s_{a b}\right)$ is given by the following equation:

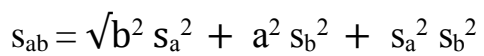

In order to conduct the test, $a b$ is divided by $S_{a b}$ to yield a critical ratio that is compared with the critical value from the standard normal distribution appropriate for a given alpha level. One of the assumptions necessary for the Sobel test is that the sample size is large, so the rough critical value for the two-tailed version of the test, assuming that the sampling distribution of $\mathrm{ab}$ is normal and that $\alpha=0.05$, is \pm 1.96 (Preacher and Hayes, 2008). Thus, it can be concluded that a more powerful strategy for testing mediation may be to require only: (1) that there exists an effect to be mediated (i.e., c $\neq 0$ ); and (2) that the indirect effect be statistically significant in the direction predicted by the mediation hypothesis (Preacher et al., 2008). To calculate the indirect effect according to Sobel (1982), the unstandardized regression coefficient obtained from regressing the mediator to predict the dependent variable (adjusting for the independent variable) $(\beta=0.522)$ should be multiplied by the unstandardized regression coefficient obtained from regressing the independent variable to predict the mediator $(\beta=0.879)$. Thus, the indirect effect of the reliability of AIS on business performance through quality of financial reporting $=0.522 \times 0.879=0.458$. In order to ensure that the indirect effect is significant, it is recommended to run the Sobel test (Sobel, 1982). The Sobel test requires the computation of the raw regression coefficient (unstandardized coefficients) and the standard error for this regression coefficient for the association between the independent variable and the mediator (path a), and the association between the mediator and the dependent variable (adjusting for the independent variable, path b) (Pierce et al., 2003). The unstandardized $\beta$ for path $\mathrm{a}=0.558$ and the standard error $=0.023$, and for path $\mathrm{b}$ the unstandardized is $\beta=0.522$ and the standard error $=0.022$. The data is then entered into the following programme to calculate the Sobel test value.

Table 6 Sobel Value Test

\begin{tabular}{|c|l|l|l|l|r|}
\hline \multicolumn{2}{|l|}{ Input } & \multicolumn{2}{|c|}{ Test Statistic } & Std. Error & P-Value \\
\hline A & 0.558 & Sobel test & 16.96322406 & 0.01717103 & 0.000 \\
\hline
\end{tabular}




\begin{tabular}{|c|l|l|l|l|l|}
\hline $\mathrm{B}$ & 0.522 & Arolan test & 16.95586362 & 0.01717848 & 0.000 \\
\hline $\mathrm{S}_{\mathrm{a}}$ & 0.023 & Goodman test & 16.9705941 & 0.01716357 & 0.000 \\
\hline $\mathrm{S}_{\mathrm{b}}$ & 0.022 & Rest all & Calculate & \\
\hline
\end{tabular}

The results revealed that the hypothesis Ho4 should be accepted since the p-value for the Sobel test $(<0.001)$ falls below the established alpha level of 0.05 , indicating that the association between the independent variable (the reliability of AIS and the dependent variable business performance) is reduced significantly by the inclusion of the mediator (quality of financial reporting) in the model; in other words, there is evidence of mediation.

\section{DISCUSSION and CONCLUSIONS}

The purpose of this study was to examine and validate the impact of the SysTrust's framework as an internal control for assuring the reliability of AIS upon business performance through the mediating role of the quality of financial reporting. In order to achieve the study objectives, and to conduct the research in a systematic approach, a conceptual framework was developed. The results indicate that the extent of SysTrust principles being implemented is considered to be moderate (i.e. $74 \%$ or 5.20). This implies that there are some variations among public listed companies in Jordan in terms of their level of reliability of AIS. This might be due to their type of business or the nature of audit IT control system. Furthermore, the implementation of the SysTrust's framework (five principles) is not obligatory in Jordan and public listed companies might implement one or more of these principles, partially or fully based on their needs.

The results of the analysis support the hypothesis stating that reliability of AIS will have a direct significant and positive influence on business performance. This result is consistent with the conclusions reached by various scholars. For instance, Al-Hanini (2015) and Mansour et al. (2017) concluded that the relationship between the reliability of AIS and business performance is significant and positive. Significant effort has also been made to understand the relationship between quality of financial reporting and business performance. This study revealed that a positive significant relationship exists between quality of financial reporting and business performance. Other studies proposed similar findings; for example, Ahmed and Duellmand (2011), Bens et al. (2002), Bushman and Smith (2001). Garcia-Lara et al. (2010) and, Gunny (2005) found that there was a positive effect for the quality of financial reporting on the overall higher performance of the company. Chen et al. (2011) also suggested that both banks and governments can get benefits of having the high- quality financial reporting because it has a positive effect on private firm's investment efficiency and financial performance. 


\section{Table 7 A Summary Comparisons between the Influence of Reliability of AIS and the Quality of Financial Reporting Upon the Business Performance}

\begin{tabular}{|l|c|c|c|c|c|c|}
\hline Hypotheses & $\begin{array}{c}\text { Multipl } \\
\mathbf{e} \\
\text { R }\end{array}$ & $\begin{array}{c}\text { R. } \\
\text { Squar } \\
\text { e }\end{array}$ & $\begin{array}{c}\text { Adjusted } \\
\text { R Square }\end{array}$ & $\begin{array}{l}\text { D } \\
\text { F }\end{array}$ & F & Sign \\
\hline Reliability of AIS & $0.822^{\mathrm{a}}$ & 0.676 & 0.665 & 11 & 63.340 & $0.000^{\mathrm{b}}$ \\
\hline $\begin{array}{l}\text { Quality of Financial } \\
\text { Reporting }\end{array}$ & $0.808^{\mathrm{a}}$ & 0.653 & 0.0649 & 4 & $\begin{array}{c}160.31 \\
7\end{array}$ & $0.000^{\mathrm{b}}$ \\
\hline
\end{tabular}

In comparing between the power of the influence of the reliability of AIS upon the business performance and its influence upon the quality of financial reporting at aggregate level, the results in Table 7 show that the variation in business performance is slightly explained by the reliability of AIS more than by the quality financial reporting measures. It could be concluded that the relationship of business performance with reliability of AIS is much better than with the quality financial reporting. This result might need further investigations in the future. The results of testing the mediating effect of quality of financial reporting on the relationship between the reliability of AIS and business performance at the aggregate level indicated that it partially mediated this relationship. In conclusion, the result has provided empirical evidence that the relationship among these construct: the reliability of AIS, business performance and the quality of financial reporting are all significantly and positively related. Furthermore, it provided support for the ability of quality of financial performance to mediate the relationship between the reliability of AIS and business performance.

Thus, this study and its findings have a number of contributions and managerial implications. In terms of theoretical contributions, this study has extant reliability of AIS literature by providing the following. First, it is explained an unexplored relationship among the reliability of AIS, the quality of financial reporting using the IASB's framework fundamental qualitative characteristics and business performance indicators (financial and non-financial). Previous research examined and linked SysTrust's framework with business performance (Casolaro and Gobbi, 2004 Mansour et al., 2017) and between the quality of financial reporting and financial business performance (Mbodo and Ekp, 2016; Tasios and Bekiaris, 2012). Second, testing the impact of the role of the quality of financial reporting as a mediating factor between the reliability of AIS and business performance measures (financial and non-financial) considered another contribution for the current study Furthermore, the SysTrust's framework implementation as an internal control system for assuring the reliability of AIS could be considered as the critical intangible resources for any business organization seeks for a reliable and effective accounting 
system in the long run. In this study, financial reporting quality justified as the mediator from contingency theory perspective where good quality and effective of information system is an integral component of a strong internal control system. Inadequate financial reporting quality might cause a lot of business operations run inefficiently and less in accordance with the demands and needs of the stakeholders. Therefore, in order to anticipate these conditions, businesses must have reliable system in generating quality information.

There are also significant implications from this study's research findings for accounting managers, auditors and financial practitioners and other decision-makers in the surveyed companies and in similar organizations. First, decision-makers should be fully aware of the importance of the reliability of AIS and the role of the implementation of SysTrust's framework principles and its relevant criteria for assuring the reliability of AIS which are find highly related to the quality of financial reporting and business performance, so that they can make the right decisions and directions for any change within their organizations. Second, as for the role of the SysTrust's framework service in the future for assuring the reliability of AIS, it can be argued that SysTrust's framework is a method of internal control that can facilitate the transition from a traditional auditing to a continuous auditing, enabling it to improve the quality of its financial reporting and business performance. Financial and IT managers should play a proactive role to support SysTrust's framework principles' implementation in their organizations. They should convince stakeholders of the importance of the SysTrust's framework principles for assuring the reliability of the AIS process, so that time and budget requirements for the adoption of the SysTrust's framework services can be allocated and justified. Stakeholders need to be convinced by the values and the strategic benefits of the SysTrust's framework principles in order to grant the required financial and non-financial support for the implementation.

However, the study has some limitations that should be considered when evaluating and generalizing its conclusions. However, the limitations discussed below can provide a starting point for future research. The study was conducted in one country, Jordan. Although Jordan is a valid indicator of prevalent factors in the wider MENA region and developing countries, the lack of external validity of this research means that any generalizations of the research findings should be taken with caution. Future research can be orientated in other national and cultural settings and compared with the results of this study. 


\section{REFERENCES}

Ahmed, A. S. and Duellman, S. (2011), "Evidence on the role of accounting conservatism in monitoring managers' investment decisions", Accounting and Finance, Vol. 51, No. 3, pp. 6090-633.

Ahmed, M. Neel, and D. Wang (2013) "Mandatory adoption of IFRS improves accounting quality? Preliminary evidence", Contemporary Accounting Research, Vol. 30 No. 4, pp. 1344-1372.

Al Hanini, E, (2015) Evaluating the reliability of the internal control on the computerized accounting information systems: An empirical study on banks operating in Jordan., Research Journal of Finance and Accounting, Vol.6, No.8, pp.176-188.

Al-Dmour, A, Abbod, M and Al-Dmour, H, (2018) "The implementation of SysTrust principles and criteria for assuring reliability of AIS: empirical study", International Journal of Accounting and Information Management, Vol.26, Issue 3 , forthcoming Issues.

Al-Dmour, A., Al-Dmour, R Masa'deh, R. (2016) "Interrelated factors influencing the adoption decision of AIS applications by SMEs in Jordan", International Business Research; Vol. 9, No. 10, pp. 45-60.

Al-Thuneibat, Ali, Awad S. Al-Rehaily, Yousef A. Basodan, (2015) "The impact of internal control requirements on profitability of Saudi shareholding companies", International Journal of Commerce and Management, Vol. 25 Issue: 2, pp.196-217

AICPA (2006), "Assurance services-definition and interpretive commentary", http://www.aicpa.org/assurance/scas/comstud/defincom/index.htm.

AICPA (2013), National Conference on Current SEC and PCAOB Developments, available at: www.webtrust.org/principles-and-criteria/item27818.pdf.

AICPA (2017), Trust Services Criteria, AICPA Publishing.

Al-Qudah., A. (2011), "The Impact of Accounting Information System on Effectiveness of Internal Control in Jordan", Interdisciplinary Journal of Research in Contemporary Business, Vol. 2, pp. 365-377.

Al-Laith, A.A.G (2012), "Adaptation of the International Control Systems with the Use of Information Technology and its Effects on the Financial Statements Reliability: An Applied Study on Commercial Banks," International Management Review. Vol. 8, No. 1, pp.12-20.

Alrowwad, A, Obeidat, B. Tarhini, A, and Aqqad, N (2017), "The impact of transformational leadership on organizational performance via the mediating role of corporate social responsibility: A structural equation modelling approach. International Business Research, Vol. 10, No. 1, pp. 199-221.

Amin, H. and Mohamed, E. (2016), "Auditors' perceptions of the impact of continuous auditing on the quality of Internet reported financial information in Egypt" Managerial Auditing Journal, Vol. 31, No. 1, pp. 111-132.

Vol.26 No.1 August 2018 
Barth, M. E. (2014). "Measurement in financial reporting: The Need for Concepts", Accounting Horizons, Vol. 28, No. 2, pp. 331-352

Baron, R. M., \& Kenny, D. A. (1986). "The moderator-mediator variable distinction in social psychological research: Conceptual, strategic, and statistical considerations". Journal of Personality and Social Psychology, Vol., 51, No.1 pp. 173-1182.

Bedard, J.C., Jackson, C.M. \& Graham, L (2005). "Issues and risks in performing SysTrust engagements: implications for research and practice," International Journal of Accounting Information Systems, Vol. 6, No. 1, pp. 55-79

Beest, V F., Braam, G. and Boelens, S. (2009)." Quality of financial reporting: measuring qualitative characteristics" Working Paper, Radboud University, Nijmegan, Netherlands, pp. 1-108.

Boritz, J.E. (2005). "IS practitioners' view on core concepts of information integrity". International Journal of Accounting Information Systems, Vol. 6, pp. 260-279.

Boritz, Eand J. H. Kearns (2000). 1999 Symposium on IS Assurance Panel Discussion on SysTrust. Journal of Information Systems: Supp., Vol. 14, No. s-1, pp. 163-176

Boritz, E., and J., Hunton, (2002). "Investigating the impact of auditor-provided systems reliability assurance on potential service recipients", Journal of Information Systems, Supplement, Vol. 16, pp. 69-88

Bukenya, M, (2014) Quality of accounting information and financial performance of Uganda's public sector, American Journal of Research Communication, Vo., 2, No. 5, pp. 183-203.

Cao, Y, Myers, L and Omer, T., (2012) "Does company reputation matter for financial reporting quality? Evidence from restatements" Contemporary Accounting Research. Vol. 29, No. 3, pp. 956-990.

Chen, F., Hope, O. K., Li, Q. and Wang, X. (2011), "Financial reporting quality and investment efficiency of private firms in emerging markets", The Accounting Review Vol. 86, No. 4, pp. 1255-1288.

Chenhall, R. (2005). "Integrative strategic performance measurement systems, strategic alignment of manufacturing, learning and strategic outcomes: An exploratory study". Accounting, Organizations and Society, Vol. 30, No. 5, pp. 39-42.

Chow, C., and Steve, W. (2006) "The use and usefulness of nonfinancial performance measures. Management accounting quarterly", European Research Studies, Volume XVII, Issue (2), 2014 pp. 41-50

Clor-Proell, S. M., Proell, C., and Warfield, T. (2014) "The effects of presentation salience and measurement subjectivity on nonprofessional investors' Fair Value Judgments", Contemporary Accounting Research, Vol. 31, No. 1, pp. 45-66. 
Costelo, A, M, Wittenberg, M, Regina. (2010) "The impact of financial reporting quality on debt contracting: evidence from internal control weakness report". SSRN Working Paper Series. Social Science Network: Rochester.

Daigle, R, Tim Kizirian and L. Dwight Sneathen, Jr. (2005), "System controls reliability and assessment effort"; International Journal of Auditing. Vol. 9, Issue 1, pp. 7990

Daneila M, Vassen E, H.J., Dameri, R, P. (2013), "Accounting information system for decision making". Springer-Verlag: Berlin.

Davila, George Foster (2005) Management accounting systems adoption decisions: evidence and performance implications from early-stage/start-up companies. The Accounting Review: Vol. 80, No. 4, pp. 1039-1068.

Dehning B, Richardson VJ. (2002) "Returns on investments in information technology: a research synthesis", Journal Information System Vol.16 No.1 pp7-30.

DeLone WH, McLean ER. (2003) "The DeLone and McLean model of information systems success: a ten-year update. Journal of Management Information System Vol. 19, No. 4, pp. 9-30.

Dess, G. G. \& Robinson, J. R. B. (1984), "Measuring organizational performance in the absence of objective measures: The case of the privately-held firm and conglomerate business unit." Strategic Management Journal, Vol. 5, No. 3, pp. 265-273

Dossi, A., \& Pateli, L. (2010). "You Learn from What You Measure: Financial and Nonfinancial Performance Measure's. Long Range Planning, Vol. 3, No. 4, pp. 498-526.

Ejoh, N. and P. Ejom (2014), "The Impact of internal control activities on financial performance of tertiary institutions in Nigeria", Journal of Economics and Sustainable Development, Vol. 5, No. 16.

Elliott, B and Elliott, J (2017), Financial accounting and reporting, $18^{\text {th }}$ edition, Pearson Higher Education.

Gaynor, L.M., Kelton, A.S., Mercer, M., and Yohn, T.L., (2016). "Understanding the relation between financial reporting quality and audit quality". Auditing: $A$ Journal of Practice and Theory, Vol. 35, No.4, pp. 1-22

Hair, J.F., Black, W.C., Babin, B.J., \& Anderson, R.E. (2010) "Multivariate Data Analysis" $7^{\text {th }}$ Edition. Prentice Hall, Upper Saddle River, New Jersey.

Hla Dwa and Teru. S (2015) "Efficiency of accounting information system and performance measures - Literature Review", International Journal of Multidisciplinary and Current Research, Vol. 3, pp. 34-45.

Harrison, J. Paul Rouse, Charl J. De Villiers (2012), "Accountability and performance measurement: a stakeholder perspective" The Business and Economics Research Journal Vol. 5, Issue 2, pp. 243-258. 
Henri C. Dekker, Tom Groot, and Martijn Schoute (2013) A Balancing Act? The Implications of Mixed Strategies for Performance Measurement System Design. Journal of Management Accounting Research: Fall 2013, Vol. 25, No. 1, pp. 7198.

Hoitash, U., R. Hoitash, and J. C. Bedard. (2008). "Internal Control Quality and Audit Pricing under the Sarbanes-Oxley Act". Auditing: A Journal of Practice \& Theory Vol. 27, pp. 5-30.

Gable, G. G., Sedera, D., \& Chan, T. (2008). Re-conceptualizing information system success: The IS-impact measurement model. Journal of the Association for Information Systems, Vol. 9), pp.377-408

IASB (2008). Exposure Draft on an improved conceptual framework for financial reporting: The objective of financial reporting and qualitative characteristics of decision-useful financial reporting information. London.

IASB, (2010). The conceptual framework for financial reporting. London: International Accounting Standards Board.

Iceman and Hillson. (2012), "Distribution of audited detected errors partitioned by internal control", Journal of Accounting, Auditing \& Finance, Vol. 5, No. 44, pp. 527-543.

Jonas, G., Blanchet, J. (2000), "Assessing quality of financial reporting", Accounting Horizons, Vol. 14, No. 3, pp. 3-53.

Joseph Canada, Steve G. Sutton, J. Randel Kuhn Jr, (2009), "The pervasive nature of IT controls: An examination of material weaknesses in IT controls and audit fees", International Journal of Accounting \& Information Management, Vol. 17, Issue 1, pp. 106-119.

Kagaari, J (2011), "Performance management practices and managed performance: the moderating influence of organizational culture and climate in public universities in Uganda", Measuring Business Excellence, Vol. 15, No. 4, pp. 36-49.

Kewo, L and, Afiah, N (2017) "Does quality of financial statement affected by internal control system and internal audit? International Journal of Economics and Financial Issues, Vol. 2, pp. 568-573.

Kieso, D, Weygandt, J and Warfield, D (2016) Intermediate Accounting, $16^{\text {th }}$ Edition, Wiley.

Kim, H., Hoskisson, R. E., and Wan, W. P. (2004). "Power dependence, diversification strategy and performance in keiretsu member firms". Strategic Management Journal, Vol. 7, No. 613, p. 634.

Klamm, B. and Watson, M. (2009) "SOX 404 Reported internal control weaknesses: A Test of COSO framework components and information technology", Journal of Information Systems, Vol. 23, No. 2, pp. 1-23. 
Konrath, L, F. (2002). Auditing - A Risk Analysis Approach, 5th Edition, And Thomson Learning: Canada.

Kinyua, J.K., Gakure, R., Gekara, M. and Orwa, G. (2015). "Effect of Internal Control Environment on the Financial Performance of Companies Quoted in the Nairobi Securities Exchange". International Journal of Innovative Finance and Economics Research Vol., 3 No. 4, pp. 29-48.

Krishnan R, Peters J, Padman R, Kaplan D. (2006). "On data reliability assessment in accounting information systems". Inf Syst Res, Vol. 16, No. 3, pp. 307-326.

Lambert, R., C. Leuz, and R. E. Verrecchia. (2007), "Accounting information, disclosure, and the cost of capital", Journal of Accounting Research, Vol. 45, pp. 385-420.

Li, Han (2016), "Social trust and internal control quality-evidence from China", International Journal of Financial Research Vol. 8, No. 2, pp. 90-97.

Mansour, E. AL Salamat, and W, Masadeh, W (2017), "The impact of reliability elements on performance indicators of Jordanian", The International Journal of Business and Finance Research Vol. 11, No. 1, pp. 87-107.

Martin J., (2005). "Trust Services: A better way to evaluate IT controls", Journal of Accountancy, Vol. 199, Issue 3, pp. 34-40.

Marie , A. Ibrahim, E and Amjad D. Al Nasser (2014), " Effects of financial and nonfinancial performance measures on customers' perceptions of service quality at Islamic Banks in UAE" International Journal of economics and Finance; Vol. 6, No. 10, pp. 34-43.

Martinez-Ferrero, J (2014), "Consequences of financial reporting quality on corporate performance, evidence at the international level", Estudios de Economia, Vol. 1, No. 1, pp. 49-88.

Masa'deh, R, Tayeh, M, Al-Jarrah, T (2015) "Accounting vs. market-based measures of firm performance related to information technology investments" International Review of Social Sciences and Humanities Vol. 9, No. 1, pp. 129-145.

Mbobo E. and N. Ekpo (2016), "Operationalizing the qualitative characteristics of financial reporting"; International Journal of Finance and Accounting, Vol. 5, No. 4, pp. 184-192.

McPhie , D (2000). "Information systems assurance and advisory services", Ernst \& Young. AICPA/CICA Systems Reliability Task Force. (2000) AICPA/CICA SYSTRUST ${ }^{\mathrm{TM}}$ Principles and Criteria”, Journal of Information Systems, Vol. 14, No. s-1, pp. 1-7.

Menna Tarek, Ehab K.A. Mohamed, Mostaq M. Hussain, Mohamed A.K. Basuony, (2017), "The implication of information technology on the audit profession in developing country: Extent of use and perceived importance", International Journal of Accounting \& Information Management, Vol. 25, Issue: 2, pp. 237255. 
Miettinen, J. (2011), "The role of audit quality on the relationship between auditee's agency problems and financial information quality." Paper presented at the Department of Accounting and Finance, University of Vaasa, Finland.

Müller, M, Edward J. Riedl, and Thorsten Sellhorn (2015) "Recognition versus disclosure of fair values" The Accounting Review: Vol. 90, No. 6, pp. 2411-2447.

Muraleethran, P (2013), "Control, activities and performance of organization", Financial Services and Management Research Vol.2, No. 4, pp. 23-40.

Nunnally, J.C. (1978), Psychometric Theory, 2nd ed., McGraw-Hill, New York, N.Y.

Ostadi, H and Abedini, K (2015) "The impact of profit quality on information disclosure in petroleum companies listed in Tehran Stock Exchange", Journal of Scientific Research and Development, Vol. 2, No. 3, pp. 4-15.

Pascan I.D. and Turcas M., (2012), "Measuring the impact of first - time adoption of international financial reporting standards on the performance of Romanian listed entities", Procedia Economics and Finance, Vol. 3, pp. 211-216

Păşcan, Irina-Doina (2015) "Measuring the effects of IFRS adoption on accounting quality: A Review; Procedia Economics and Finance Vol. 2, pp. 580-587.

Pomeroy, B., \& Thornton, D. B. (2008), "Meta-analysis and the accounting literature: The case of audit committee independence and financial reporting quality" The European Accounting Review, Vol. 17, No. 2, pp. 305-330.

Preacher, K and Andrew F. Hayes (2008) "Sociological Association. Asymptotic and resampling strategies for assessing and comparing indirect effects in multiple mediator models", Behavior Research Methods, Vol. 40, No. 3, pp. 879-891.

Pugliese, A. and Halse, R (2000) "SysTrust and WebTrust: technology assurance opportunities," CPA Journal, Vol. 70, No. 11, pp. 28-34.

Rahmani, H., and Jabari, H. (2015) "A Model for evaluating the impacts of qualitative characteristics on the usefulness of financial reporting". International Journal of Management, Accounting and Economics, Vol. 2, No. 4, pp. 2-11.

Rajgopal, S., and Venkatachalam, M. (2011), "Financial reporting quality and idiosyncratic return Volatility". Journal of Accounting and Economics, Vol. 5, No. 1-2, pp. 1-20.

Ramdany (2015), "Influence the quality of accounting information systems and the effectiveness of internal control on financial reporting quality", Research Journal of Finance and Accounting', Vol. 6, No. 6, pp. 141-149.

Ricchiute, D, N. (2006) Auditing, $8^{\text {th }}$ edition. Thomson Learning: Singapore.

Richard, P. J., Devinney, T. M., Yip, G. S., \& Johnson, G. (2009). "Measuring organizational performance: towards methodological best practice". Journal of Management, Vol. 35, No. 3, pp. 718-804.

Romney M and Steinbart PJ (2017) "Accounting Information Systems. $14^{\text {th }}$ edition, Pearson Prentice Hall. 
Salehi, M., Rostami, V., \& Mogadam, A. (2014)." Usefulness of accounting information system in emerging economy: Empirical evidence of Iran. International Journal of Economics and Finance, Vol. 2, pp. 186-200.

Santos, J and L. Brito (2012), "Toward a subjective measurement model for firm performance", BAR, Rio de Janeiro Vol. 9, Special Issue, Part 6, pp. 95-117.

Saira, K., Zariyawati, M. A., \& Annuar, M. N. (2010). Information system and firms' performance: the case of Malaysian small medium enterprises. International business research, Vol. 3, p. 28.

Sobel, M. E. (1982)," Asymptotic confidence intervals for indirect effects in structural equation models. In S Leinhardt (Ed.), Sociological Methodology pp. 290-312.

Taghian, M., Deesouza, C. and Polonsky, M. J. (2015) "A stakeholder approach to corporate social responsibility, reputation and business performance". Social Responsibility Journal, Vol. 11, No. 2, pp. 340-363.

Taiwo, J.N. -Agwu M. Edwin, (2016) "Effect of ICT on accounting information system and organizational performance", European Journal of Business and Social Sciences, Vol. 5, No. 2, pp. 1-15.

Tasios, S. and Bekiaris, M. (2012) "Auditor's perceptions of financial reporting quality: The Case of Greece". International Journal of Accounting and Financial Reporting, Vol. 2, No. 1, pp. 57-74.

Topash, N.K. (2014), "Evaluation of efficiency of accounting information systems: A study on mobile Telecommunication Companies in Bangladesh." Global Disclosure of Economics and Business, Vol. 3, No. 1, pp. 40-55.

Vij, S and Bedi, H. (2016). "Are subjective business performance measures justified?" International Journal of Productivity and Performance Management Vol. 65, No. 5, pp. 603-621.

Vissser C.B., Erasmus P.W. (2009) The Management of Public Finance: A Practical Guide, Oxford: Oxford University Press.

Wall, T., Michie, J., Patterson, M., Wood, S., Sheehan, M., Clegg, C., \& West, M. (2004). "On the validity of subjective measures of company performance", Personnel Psychology, Vol. 57, pp. 95-118.

Yurisandi, T and Puspitasari, E (2015) "Financial quality reporting, before and after IFRS adoption using NiCE qualitative characteristics measurement" Procedia - Social and Behavioral Sciences, Vol. 2, No. 11, pp. 644-652.

Zulkarnain, M, S. (2009) "Accounting Information System (AIS) and Knowledge Management: A Case Study". American Journal of Scientific Research, pp. 3644. Euro Journal Publishing, Inc., USA. 
Vol.26, No.1 August 2018

CCentre for Indonesian Accounting and Management Research Brawijaya University 